\title{
The Use of Mobile Phones by South African University Students
}

\author{
David North, Kevin Johnston, and Jacques Ophoff \\ University of Cape Town, South Africa
}

\author{
NRTDAV004@myuct.ac.za jacques.ophoff@uct.ac.za \\ kevin.johnston@uct.ac.za
}

\begin{abstract}
Mobile phones are an integral part of our modern lives. This study explores the use and role of mobile phones among South African university students. Four main categories are used to examine the students' mobile phone use: reasons to use mobile phones, pattern of mobile phone use, purchasing factors, and behaviour-related issues. Through a quantitative approach data was collected from 362 participants using a survey.

The key findings indicate that the main reason South African university students (mainly from the University of Cape Town) use a mobile phone is for socializing, as well as for safety and privacy purposes. Usability and price emerged as the top purchasing factors. The respondents showed some signs of addiction to their mobile phones. Differences in mobile phone use by gender were found, with female students showing increased mobile phone use for safety and socializing, interest in brand and trends, as well as signs of addiction. The findings could prove beneficial to marketers, mobile phone developers, universities, parents, and researchers exploring mobile phone adoption and usage pattern in a developing country such as South Africa.
\end{abstract}

Keywords: Mobile phone, reasons to use, usage patterns, purchasing factors, behavioural issues, gender differences

\section{Introduction}

In the $21^{\text {st }}$ century the mobile phone is an integral part of everyday life, only found strange when it is absent. As stated by Katz and Aakhus (2002), "the spread of mobile phones is affecting people's lives and relationships and affects how people interact when face to face or, rather and increasingly, face-to-face-to-mobile-phone-face, since people are ever more likely to include the mobile phone as a participant in what would otherwise be a face-to-face dyad" (p. 31).

This study aims to discover the patterns of how South African university students use mobile

Material published as part of this publication, either on-line or in print, is copyrighted by the Informing Science Institute. Permission to make digital or paper copy of part or all of these works for personal or classroom use is granted without fee provided that the copies are not made or distributed for profit or commercial advantage AND that copies 1) bear this notice in full and 2) give the full citation on the first page. It is permissible to abstract these works so long as credit is given. To copy in all other cases or to republish or to post on a server or to redistribute to lists requires specific permission and payment of a fee. Contact Publisher@InformingScience.org to request redistribution permission. phones in their daily lives. This is deemed interesting and relevant because South Africa has a mobile penetration rate of over $100 \%$, consisting of a rich diversity of mobile phones ranging from entry-level feature phones to smartphones (International Telecommunication Union, 2013). The study looks at four main themes of mobile phone use: reasons to use mobile phones (socialising, safety, privacy and status), pattern 
of mobile phone use (average number of calls made and received daily etc.), purchasing factors (brand, trend, price, aesthetic values, usability), and behaviour related issues (addiction, using mobile phones in lectures, driving) (Balakrishnan \& Raj, 2012).

Mobile phones are known to be very popular among university students, increasing their social inclusion and connectedness as well as providing a sense of security as they can contact others in times of distress or emergency (Balakrishnan \& Raj, 2012). Although there are many benefits of using a mobile phone, there can also be negative effects on the users and environment. Lectures are disrupted when mobile phones are used at inappropriate times (Walsh et al., 2010), and using a mobile phone whilst driving may lead to an increased risk of an accident (Hong, Chiu, \& Huang, 2012; Walsh et al., 2010). Other negative consequences of mobile phone use include addiction, manifested as over dependency, which can cause problems such as emotional stress, damaged relationships, and falling literacy (Balakrishnan \& Raj, 2012). According to Walsh et al. $(2008,2010)$ university students were reported to show signs of cognitive salience, whereby students think about their phones when they are not using them, as well as behavioural salience, whereby the students constantly check their mobile phones for missed calls or messages.

The research was a quantitative study whereby university students were asked to complete a survey which was initially designed by Balakrishnan and Raj (2012) to explore the relationships between Malaysian youth and their mobile phones. The rest of the paper is presented as follows. In the next section the related literature is reviewed, motivating the research questions on which the study is based. The third section presents the research methodology and the following section presents the research results. The fifth section presents the findings of the study before a conclusion is drawn in the last section.

\section{Literature related to Mobile Phone use}

Many studies have looked at mobile phone use amongst university students in other (not South Africa) countries (Balakrishnan \& Raj, 2012; Baron \& Campbell, 2010; Beaver, Knox, \& Zusman, 2010; Hong et al., 2012; Ling \& Horst, 2011; Lobo \& Joshma, 2013; Ogunyemi, 2010; Suominen, Hyrynsalmi, \& Knuutila, 2014; Walsh et al., 2010). Within South Africa research done by Kreutzer (2009) focused on the use of mobile phones by low-income youth. Apart from a study by Chigona, Kamkwenda and Manjoo (2008) which focused on the use of mobile Internet, no definitive literature on how South African University students use and perceive mobile phones has been found. The literature review therefore focuses on the use of mobile phones by university students from different parts of the world and how mobile phone usage is perceived by university students. It is acknowledged that it is difficult to draw conclusive arguments of mobile phone use as culture, values, and belief systems differ around the world and play a part in the perception and use of technology.

\section{Uses and Gratification Theory}

Motivations to use technology, ranging from radio and television to digital TV and now the internet and mobile phones, can be explained by the Uses and Gratification theory (UGT) (Shao, 2009; Shin, 2010). UGT focuses on why consumers turn to technology to satisfy their social and psychological needs (Balakrishnan \& Raj, 2012). UGT implies that consumers are actively involved in their decision to use, and how to use technology in order to fulfil certain needs (Leung \& Wei, 2000; Leung, 2007).

UGT is considered one of the most appropriate perspectives for investigating why audiences choose to deal with different technologies (Balakrishnan \& Raj, 2012; Shao, 2009). As stated by Shao, "whenever a new technology enters the stage of mass communication, people's motivations to use this technology have been examined through this perspective" 2009, p.9). 
Previous studies used UGT to examine the gratifications and use of mobile phones in university students (Auter, 2007; Balakrishnan \& Raj, 2012; Dresler-Hawke \& Mansvelt, 2008; Grellhesl \& Punyanunt-Carter, 2012; Leung \& Wei, 2000; Leung, 2007; Ogunyemi, 2010). Results suggest a large number of gratifications for mobile phone use which include: information exchange, conversation and socializing, information viewing, entertainment, education, escape and diversion, reassurance, fashion and status (Balakrishnan \& Raj, 2012; Grellhesl \& Punyanunt-Carter, 2012; Leung, 2007; Ogunyemi, 2010).

The sections that follow explore the use of mobile phones by university students, using a UGT framework as shown in Figure 1. According to Balakrishnan and Raj (2012), "four main categories were identified, namely, reasons to use mobile phones, pattern of mobile phone usage, purchasing factors and behaviour related issues. Some of the example items for each of these categories are shown in the framework" (p. 266). The literature review focuses on each of the four categories of the model separately.

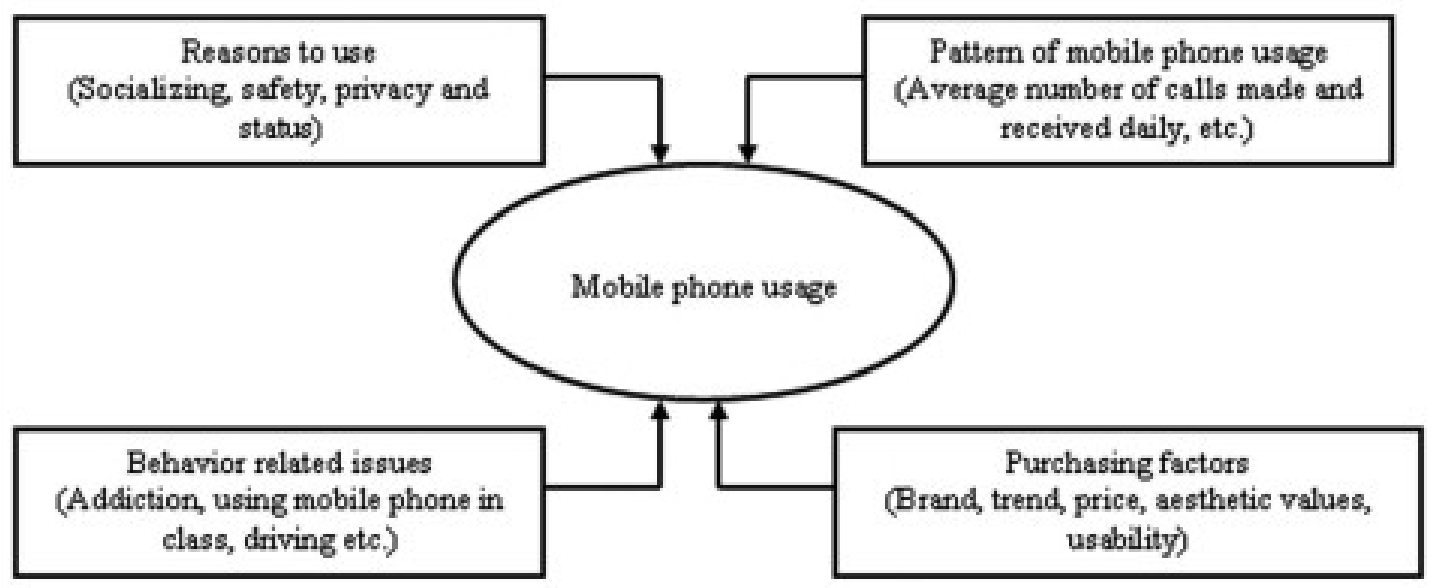

Figure 1: Uses and Gratification Framework (Balakrishnan \& Raj, 2012)

\section{Reasons to Use Mobile Phones}

The most commonly found reason for owning a mobile phone by university students in Australia and Malaysia was the convenience of being able to contact others and be contacted regardless of time and location through calls and messaging (Balakrishnan \& Raj, 2012; Walsh, White, \& Young, 2008). Malaysian students' most common use of mobile phones was for privacy purposes, allowing freedom of communication without filtering or interference by parents or siblings(Balakrishnan \& Raj, 2012). The three main reasons university students' need to communicate is for inclusion (the need to belong), control (the need to give instructions to others or be given instructions) and affection (the need to love or be loved) (Auter, 2007; Ogunyemi, 2010). While being readily contactable was found to be an advantage, it was also noted that it can be a disadvantage, as contact could occur at inappropriate times (Walsh, White, \& Young, 2008).

Apart from being a communication device, the mobile phone is used by university students in the United Kingdom (UK) and Australia for many other functions, such as alarm clock, camera, music player, diary and phonebook (Ogunyemi, 2010; Walsh et al., 2008). The interviews conducted in a study by Walsh, White and Young (2008) found that there can be disadvantages of having all these features on one device; for example, if someone lost their phone they would lose $90 \%$ of their friends and family's contact numbers.

University students in the United States of America (USA) said that owning a mobile phone is essential for keeping in contact with their parents, to ask for advice or get emotional support 
(Chen \& Katz, 2009). Some parents in the USA insist that their children in university carry their phones at all times for safety purposes (Beaver et al., 2010; Lenhart, Ling, Campbell, \& Purcell, 2010). Whilst Ogunyemi (2010) found that African teenagers' mobile phone usage was greatly affected by their parents in other ways too, an increased bill from excessive use would lead to scrutiny by their parents therefore forcing the students to use their phones less than they intended.

University students in the USA and Malaysia were found to consider their mobile phone as their primary phone, as opposed to using their home landline, in order to keep their conversations private from their parents and siblings (Auter, 2007; Balakrishnan \& Raj, 2012). Portability also provided students with more privacy by allowing conversations to take place away from authority figures (Auter, 2007). The privacy that mobile phones provide give university students more freedom in their day to day lives (Balakrishnan \& Raj, 2012).

Previous research from the USA, Netherlands and Malaysia found that mobile phones have surpassed their initial purpose as a communication device, have become a status symbol of social progress to users, and is somewhat of a fashion item (Balakrishnan \& Raj, 2012; Bouwman, Carlsson, Walden, \& Molina-Castillo, 2008; Cotten, Anderson, \& Tufekci, 2009). On the other hand research from New Zealand and the USA disagrees, finding that mobile phones are no longer considered a status symbol but a 'necessity' (Dresler-Hawke \& Mansvelt, 2008; Wei, 2008). Even so, social differentiation is still likely to occur through personalisation such as ringtones, covers and brand (Dresler-Hawke \& Mansvelt, 2008; Petruzzellis, 2010).

Mobile phones are not entirely accepted as part of school and university culture in Canada (Walsh \& Kelly, 2012) although, they are a powerful tool for learning (Kreutzer, 2009; Roberson \& Hagevik, 2008). A Singapore school incorporated a collaborative game, designed for mobile phones, into their curriculum. This integration resulted in increased participation and learning by the students (Roberson \& Hagevik, 2008). Likewise, in countries such as China, Germany and Japan, students are using their mobile phones to learn English (Roberson \& Hagevik, 2008). There is a positive correlation, in South Africa, between owning a mobile phone and academic performance (Kreutzer, 2009). Therefore students enthusiasm towards mobile phones can be used to enhance learning (Roberson \& Hagevik, 2008).

\section{Gender differences in reasons to use mobile phones}

Beaver et al. (2010) found that parents of university students in the USA are more worried about their daughters' safety than they would be for their sons, therefore parents may be more insistent that their daughters carry a mobile phone at all times. Safety was found to be a major reason why females use mobile phones in Malaysia and New Zealand (Balakrishnan \& Raj, 2012; DreslerHawke \& Mansvelt, 2008), as well as to help them not feel lonely (Dresler-Hawke \& Mansvelt, 2008). Female students in Malaysia and Australia use their phones as a security device, to contact others when they are in danger (Balakrishnan \& Raj, 2012; Walsh et al., 2010). Baron and Campbell (2010) touch on strange but effective methods that Swedish female students use mobile phones for in order to keep themselves safe. Given females greater physical vulnerability in encounters with a stranger, the encounter could be avoided by pretending to be busy on her mobile phone (Baron \& Campbell, 2010).

A study on the gratifications of mobile phone use by Grellhesl and Punyanunt-Carter (2012) showed that female university students in the USA scored higher than males in the gratification of mobile phones for relaxation and escape. The female students similarly scored higher than male students in the total gratification from mobile phone use, showing that female students feel stronger ties to their mobile phones than male students (Grellhesl \& Punyanunt-Carter, 2012). 


\section{Mobile Phone Usage Pattern}

Mobile phones have become web enabled devices that may be constantly connected to the internet, providing more communication than just phone calls and Short-Messaging-Services (SMS) such as; social media and Instant Messaging (IM) (Auter, 2007; Beaver et al., 2010). University students in the USA and South Africa access websites through mobile phones, especially amongst the lower income youth who do not own computers (Brown, Campbell, \& Ling, 2011; Kreutzer, 2009; Lenhart et al., 2010). Therefore students are spending an ever increasing amount of time on their phones replying to the increased sources of communication (Auter, 2007; Beaver et al., 2010; Kreutzer, 2009).

University students in Malaysia were found to make between 1 and 5 calls per day, with the majority of calls going to friends and family (Balakrishnan \& Raj, 2012). Malaysian university students tend to receive more calls than they make, this may be due to low budgets (Balakrishnan \& Raj, 2012).

Text messaging (IM and SMS) was found to be the most prevalent use of mobile phones by students in the USA (Brown et al., 2011), with the majority of students sending and receiving between 30 and 80 text messages a day (Lenhart et al., 2010). Students in the USA prefer to text rather than call, with the majority of texting taking place through the mobile internet (Brown et al., 2011).

Much of the mobile phone calls by university students in New Zealand occurred to maintain friendships, keep in contact with family and most commonly, to make social arrangements, demonstrating that mobile phones facilitate rather than disrupt social communication (Dresler-Hawke \& Mansvelt, 2008).

\section{Gender differences in mobile phone usage pattern}

Research found that female university students from the USA are more likely to have conversations over mobile phones more regularly (Baron \& Campbell, 2010; Beaver et al., 2010), and Malaysian female students have lengthier conversations than male students (Balakrishnan \& Raj, 2012). Male students in the USA and Malaysia generally make calls to make arrangements, whilst females are more likely to make calls for a social chat (Balakrishnan \& Raj, 2012; Grellhesl \& Punyanunt-Carter, 2012). Ogunyemi (2010) found that African male students living in the UK prefer to text in order to show affection whilst the female students prefer to receive a call rather than a text. Beaver et al. (2010) and Baron and Campbell (2010) both agree that this is because women are more relationship oriented than males, and therefore use mobile phones to facilitate social interaction.

Mehrotra and Nguyen (2012), who performed a study in Rwanda, found the opposite to be true. Mehrotra and Nguyen (2012) established that men spend more time in conversation over a mobile phone per day than women do, with women spending the majority of their talking time at night. Although the majority of the sample used in the study was of an older age group than university students, and Rwanda is still a very under developed country in global terms whereby the mobile phone adoption rate amongst women is low (Mehrotra \& Nguyen, 2012).

Research done in the USA and Malaysia found that female university students are more likely to keep in contact with their family members, to share experiences and seek emotional support. While male university students only contact their parents "to keep them happy" (Balakrishnan \& Raj, 2012; Chen \& Katz, 2009).

Although male students from the USA use mobile phones less in conversation, they were found to participate in videogames a lot more often than females, which may result in male students 
spending a greater amount of time on their mobile phones (Jackson et al., 2008; Jackson, von Eye, Fitzgerald, Zhao, \& Witt, 2010).

Baron and Campbell (2010) mentioned that female students in the USA were possibly more troubled by reachability, because female students send and receive more text messages than male students. Male students in New Zealand were more likely to use text messaging to make new contacts than female students, whilst female students prodomenently used text messaging for communicating with close friends and family (Dresler-Hawke \& Mansvelt, 2008).

In summary, the literature finds that university students tend to make 1-5 calls and send $30-80$ text messages per day. University students tend to receive more calls than they make, with most of their calls aimed at maintaining friendships, keeping in contact with family and making social arrangements. Text messaging seems to be the most prevalent use of mobile phones. Female university students tend to make moreand lengthier calls, send more text messages, and are more likely to keep in contact with their parents than male university students. Whilst male students were more likely to use their mobile phones to play video games and make new friends.

\section{Purchasing Factors}

When purchasing a mobile phone, university students in Greece consider certain features and characteristics of the phone more important than others (Economides \& Grousopoulou, 2009). The desired features have to be weighed up and compared to the extra price for the added feature on the mobile phone, as price is a major factor for university students in Malaysia and Greece (Balakrishnan \& Raj, 2012; Economides \& Grousopoulou, 2009). Students know about the "curse of technology markets" referring to the fact that new technologies reduce in price over time. The expected price reduction results in some Finnish students purchasing older models of mobile phones (Karjaluoto et al., 2005).

Almost all university students in new Zealand own a mobile phone (Dresler-Hawke \& Mansvelt, 2008; Hargittai \& Kim, 2010) and most New Zealand students purchased a new mobile phone, not because they wanted a new model, but mainly because their old phone was no longer functional (Dresler-Hawke \& Mansvelt, 2008).

When purchasing a mobile phone, university students in Taiwan were less interested in the practical functions (e.g. battery life) and more interested in the functions related to entertainment, such as taking pictures easily (Tsai, 2012). Malaysian, Finnish and Italian university students' three main considerations when purchasing a mobile phone were found to be brand, trend and price (Balakrishnan \& Raj, 2012; Karjaluoto et al., 2005; Petruzzellis, 2010) whilst usability was ranked the lowest factor to be taken into consideration amongst Malaysian university students in a study by Balakrishnan and Raj (2012).

\section{Gender differences in purchasing factors}

Literature shows that differences exist between males and females with regard to what attracts a user to buy a particular mobile phone (Karjaluoto et al., 2005). The literature similarly shows that the gender differences are not constant throughout the world - different countries show different results with regard to male and female purchasing factors.

Ogunyemi (2010) acknowledged a difference in mobile phone cultures amongst African teenagers living in the United Kingdom (UK). Females preferred smaller phones that look good with fewer features while males prefer bulky phones with more features.

Whilst research by Balakrishnan and Raj (2012) found that Malaysian females were more interested in usability of a mobile phone than males, who preferred to have the best brand. 
Korean studies found that females tended to follow trends and popularity when purchasing a mobile phone, whilst males considered function as the most important factor when purchasing a mobile phone (Kim \& Park, in press).

Research in Taiwan showed that whilst students in general were more interested in the entertainment functionalities of a mobile phone, female students were particularly interested in the entertainment-related and social-related software applications that the mobile phone can offer (Tsai, 2012). On the other hand, Hargittai and Kim (2010) did not find any statistic differences between males and females regarding entertainment-related purchasing factors of mobile phones (Hargittai \& Kim, 2010).

A study in Greece indicated that females cared more about appearance and design and were less worried about price than males. Whilst the study showed that males were more concerned about the mobile phone's security, battery life and processing speeds (Economides \& Grousopoulou, 2009).

Literature says that the mobile phone purchasing factors amongst university students are brand, trend, price, aesthetic values and usability. Gender differences exist with regard to purchasing factors of a mobile phone and vary significantly according to the country that the research was conducted in.

\section{Behaviour Related Issues}

Ogunyemi (2010) found an association between individual behaviour and mobile phones. People who have high tech phones tend to live their lives through their phones which reflects on their character, showing that they like to be liked or are competent and organized (Ogunyemi, 2010). Likewise, someone with a broken or half functional phone depicts that they are disorganized (Ogunyemi, 2010). Other research found a positive relationship between university students' anxiety, mobile phone addiction and mobile phone usage behaviour, reinforcing that there is a relationship between students character and their mobile phone use (Hong et al., 2012). However, Hong, Chiu, and Huang's (2012) sample was solely comprised of female students therefore the results can not be acurately applied to all university students.

Given the reasons to use a mobile phone (ease of contact, privacy, safety etc.) it is not surprising that students become very attached to their mobile phones (Balakrishnan \& Raj, 2012). Studies have shown that mobile phone addiction can occur amongst students with the majority of students checking their phone regularly for missed calls, leaving their phones on at all times and feeling distressed without their phone on them (Chung, 2011; Dresler-Hawke \& Mansvelt, 2008; Walsh et al., 2008; Walsh et al., 2010).

Walsh et al. (2008) suggest that mobile phone addiction could possibly be a positive addiction in which benefits are derived from the behaviour, such as facilitating young people's connectedness to each other and improving ones self-esteem by feeling loved by others. Walsh et al. (2010) go on to say that a positive addiction can become a negative addiction if adverse consequences such as withdrawal or reliance on the device over-ride the benefits of the behaviour.

Ogunyemi (2010) found that African teenagers living in the UK over used some of the mobile phone features, such as extensive text messaging, mobile games and the use of missed calls in order to be called back by the recipient (Ogunyemi, 2010). Extensive use of text messaging was also an issue found in a study done on university students in Norway, it was found that no other age group sends anywhere near the number of text messages as teenagers and young adults do (Ling et al., 2011). Almost a third of university students in New Zealand were found to text while driving and while talking face to face with someone, and almost half would text while in class 
(Dresler-Hawke \& Mansvelt, 2008). Most university students are avid users of text messaging (Dresler-Hawke \& Mansvelt, 2008; Lenhart et al., 2010).

African university students living in the UK seem to have developed a strong social etiquette with regards to mobile phone use (Ogunyemi, 2010). Studies found that the use of mobile phones in school, lectures and in restaurants or family meals was regarded by students to be inappropriate (Balakrishnan \& Raj, 2012; Baron \& Campbell, 2010; Campbell, 2006; Ogunyemi, 2010) with the majority using text messages in those locations (Balakrishnan \& Raj, 2012). Whilst using a mobile phone when moving through public space such as on public transport or walking on the street is regarded as more acceptable by students in the USA (Baron \& Campbell, 2010). Although Campbell (2006) agrees that students in the USA aged between 18 and 23 regard using mobile phones in private settings as inappropriate, they are a lot more accepting of the action when compared to older age groups (Campbell, 2006). While university students in Malaysia and the USA acknowledge the negative aspects of mobile phones, they are more susceptible and tolerant to inappropriate mobile phone use than older age groups (Balakrishnan \& Raj, 2012; Baron \& Campbell, 2010; Campbell, 2006). "Growing experience with the use of mobile phones will iron out many of the glitches now current. However, like in the case of driving a car, it is important to ensure that correct habits are formed early" (Srivastava, 2005, p. 128-129).

\section{Gender differences in behaviour related issues}

Females were found to be more strict with politeness norms than males, such as using one's phone in private settings such as a restaurant or lectures (Balakrishnan \& Raj, 2012; Baron \& Campbell, 2010; Beaver et al., 2010). Baron and Campbell (2010) found that gender is just one variable that affects mobile politeness norms, variables such as culture may also be critical. For example; Italians do not use their phones while sitting at the dinner table, Koreans use their mobile phones more than most, and Japanese people are not bothered by reachability (Baron \& Campbell, 2010).

A study in New Zealand by Dresler-Hawke and Mansvelt (2008) indicated that over half of the university students admitted to constantly checking their mobile phone for missed calls and messages, the majority of which were female students. Showing that female students showed a greater sign of addiction towards their mobile phone (Dresler-Hawke \& Mansvelt, 2008). Interestingly, Dresler-Hawke and Mansvelt (2008) also found that the majority of students (84\%) turned off their phones or turned them onto silent in situations where mobile phone use was forbidden; again, female students were more likely to do so than males (Dresler-Hawke \& Mansvelt, 2008). These results show that whilst female students are more likely to become addicted to mobile phones, they oddly also have better mobile phone etiquette (Dresler-Hawke \& Mansvelt, 2008).

Male students in the USA were found to not like to follow the 'rules of mobile communication' (eg. responding to text messages immediately), possibly because they were less troubled by reachability, while female students were possibly more troubled by reachability (Baron \& Campbell, 2010).

In summary, the literature finds that university students' behaviour-related issues include signs of addiction, leaving their phones on at all times, social etiquette, using mobile phones in class, lectures and in restaurants, and using mobile phones whilst driving. Gender differences exist with regard to mobile phone addiction, reachability and politeness norms, with female university students showing a stronger relationship with those behaviours. 


\section{Research Questions}

Due to the lack of research assessing mobile phone adoption and use among South Africans (Kreutzer, 2009), the purpose of this study is to find the uses and gratification of mobile phones by South African university students. From the literature, the following research questions are identified:

1. What are the reasons for using a mobile phone among South African university students? And what are the gender differences in reasons to use mobile phones among South African university students?

2. What is the mobile phone usage pattern among South African university students? And what are the gender differences in the mobile phone usage pattern among South African university students?

3. What are the factors considered by South African university students when purchasing a mobile phone? And what are the gender differences in the purchasing factors among South African university students?

4. What are the behaviour related items of mobile phone use with regard to South African university students? And what are the differences with regard to gender?

\section{Research Methodology}

The study was descriptive in nature, with the use of a survey to gather the data. The research method selected for this study was a survey approach because it allowed for a larger sample to be gathered, as opposed to interviews or other forms of data gathering (Welman et al., 2005). The survey was used to obtain the demographics, behaviour, opinions and attitudes of South African university students with regard to their use of mobile phones.

Data was collected from South African university students, the majority being from the University of Cape Town (UCT). The data was gathered using an online survey with 33 questions, taken from a study done by Balakrishnan and Raj (2012). Balakrishnan and Raj's (2012) did reliability tests on the survey using Cronbach Alpha, and found an acceptable level of internal consistency with a value of 0.73 . The survey was made available online to all students at four South African universities in the middle of 2013. The survey was administered using Qualtrics.com, and structured as follows:

- Demographics of the respondent and general information about their mobile phone. This includes age, university they attend, country of origin, gender, year of study, undergraduate or postgraduate, brand of mobile phone, type of mobile phone (e.g. smartphone, feature phone, basic phone), prepaid or contract payment method and who pays for their mobile phone. A Smartphone offers a wide variety of features that use advanced computing capability and connectivity including high-megapixel cameras, and the ability to edit documents and photos. A feature phone has features such as cameras, touchscreen, GPS navigation, $\mathrm{Wi}-\mathrm{Fi}$, and mobile broadband access, while a basic phone allows users to perform basic features such as make/receive calls and send/receive text messages.

- Purchasing factors. The respondents were asked "When purchasing a mobile phone, how important are these factors?" The factors (brand, trend, price, aesthetic values, usability) were listed and the question used a six point Likert scale with 1 being "not important" and 6 being "very important" for the respondents to rate how important each factor is to them.

- Reasons to use mobile phones. As with purchasing factors, a six point Likert scale was used. The respondents were asked "My mobile phone is for?" with the reasons (privacy, safety, socializing, as a status symbol") listed. 
- Mobile phone usage pattern. Balakrishnan and Raj (2012) used a 24 hour diary to record the data for this section of the research. The diary approach was not used in this research, rather an anonymous online survey was used to gather multiple responses. This research included the mobile phone usage pattern section in the survey and asked respondents to approximate their mobile phone use. The questions were multiple choice questions that covered the following areas: how many times the respondent uses their mobile phone a day, calls made per day, calls received per day, to whom the calls are made to/from, average length of calls, main purpose of the calls made/received and the approximate number of text messages sent per day. In each case students were offered a range of choices, for example number of times a mobile was used per day had ranges of 0-5, 6-10, 11-20, 2140, 41-60, 60-100, and 100+.

- Behaviour related issues. A six point Likert scale was used for this section of the survey. The respondents were given statements and they had to state whether they agree or disagree with the statement on a scale of one to six as shown in Figure 2.

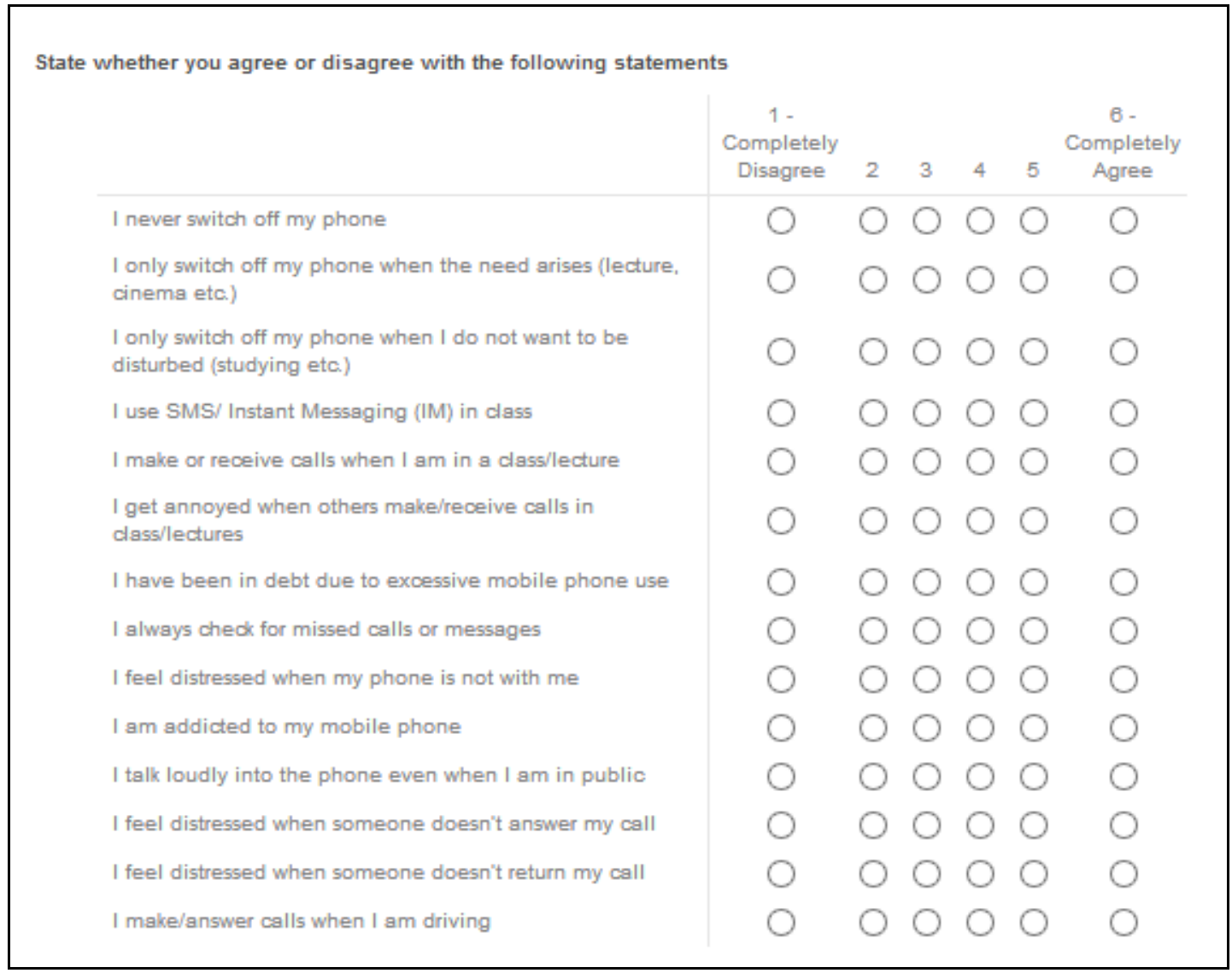

Figure 2: Behaviour related questions in the survey

\section{Results}

The gathered data was analysed using Qualtrics statistics, reporting and cross tabulation functionalities. Although the survey was advertised in five universities, the researchers had no control over how, when or where it was advertised, this resulted in less than $10 \%$ of responses from out- 
side of the University of Cape Town (UCT). As a consequence, the results are strongly biased towards UCT. Of the respondents, $85 \%$ were undergraduates.

\section{Demographics}

There were a total of 362 respondents (male $=198$, female $=164)$ with a mean age of $20.70(\mathrm{SD}$ $=1.97)$. Of these 309 were under-graduates whilst 52 were post-graduates. The majority of students $(60 \%)$ were in their first or second year of university. As over $90 \%$ of respondents attended the University of Cape Town (UCT), the results were not analysed by university.

Exactly half the respondents used pre-paid mobile contract, the other half were on 24 month contracts. Eighty-three per cent of the 179 contract respondents, did not pay their own bills. Blackberry seems to be the most favoured brand of mobile phone with $29 \%$ of ownership, followed by Samsung (24\%), Apple (19\%), Nokia (16\%) and other brands sharing the remainder of the respondents. Three respondents (1\%) did not own a mobile phone, or had not owned one recently. Of the respondents that did own a mobile phone, $90 \%$ had smartphones, $6 \%$ had feature phones and $4 \%$ had basic phones. The majority of basic $(69 \%)$ and feature phones $(67 \%)$ that the respondents own are made by Nokia.

It is interesting to note that the $63 \%$ of the older respondents ( 22 years and older) are on prepaid payment schemes, compared to $35 \%$ of the younger students. Respondents over the age of 21 were more likely to pay for their own mobile phones, and the majority of postgraduates paid for their own mobile phones (63\%). Most of the Samsung (60\%) and Apple (71\%) owners were on contract payment schemes, the rest of respondents that owned different brands are mostly on prepaid paid schemes. The majority of respondents that own basic phones $(77 \%)$ and feature phones $(86 \%)$ are on prepaid schemes.

\section{Reasons to Use Mobile Phones}

Table 1 shows the statements pertaining to reasons to use mobile phones and their mean values and standard deviations. As shown by the mean values, the main reason UCT university students use a mobile phone seem to be for socializing, followed by for safety and privacy purposes. UCT university students do not seem to use their mobile phone as a status symbol.

Table 1: Reasons to use mobile phones in the rank of ascending mean values

\begin{tabular}{lll}
\hline Statements & Mean & SD \\
\hline My mobile phone is for: & & \\
Socializing & 5.03 & 1.24 \\
My Safety & 4.16 & 1.43 \\
My Privacy & 4.14 & 1.57 \\
As a status symbol & 2.18 & 1.41 \\
\hline
\end{tabular}

Independent one-tailed t-tests were conducted in order to see if any significant differences existed amongst male and female respondents; the results are shown in Table 2. The results indicate significant gender differences for using a mobile phone for safety $(\mathrm{t}=4.980, \mathrm{p}<0.001)$, privacy $(\mathrm{t}=$ $2.474, \mathrm{p}=0.014)$ and socializing $(\mathrm{t}=2.187, \mathrm{p}=0.029)$, with the females focusing more on these than the males. 
Table 2: t-test for reasons to use mobile phones based on gender

\begin{tabular}{llll}
\hline Statements & t-value & p-value & Mean \\
\hline My mobile phone is for: & & & \\
Socializing & 2.187 & 0.029 & $\mathrm{M}=4.91, \mathrm{~F}=5.19$ \\
My Safety & 4.980 & 0.000 & $\mathrm{M}=3.82, \mathrm{~F}=4.55$ \\
My Privacy & 2.474 & 0.014 & $\mathrm{M}=3.95, \mathrm{~F}=4.36$ \\
As a status symbol & 0.534 & 0.594 & $\mathrm{M}=2.15, \mathrm{~F}=2.23$ \\
\hline
\end{tabular}

It is interesting to note that respondents that own a basic mobile phone (e.g. Nokia 1100), do not consider their phone for socializing $(M=3.23)$ as much as feature phone $(M=4.90, p=0.007)$ and smart phone owners $(\mathrm{M}=5.12, \mathrm{p}=0.002)$. Respondents whose parents paid for their mobile phone were more concerned about safety as a reason to use their mobile phone compared to respondents that bought their own mobile phone $(\mathrm{p}=0.034)$.

\section{Mobile Phone Usage Pattern}

The results indicate that there is a large variation between the respondents with regard to mobile phone usage patterns. The breakdown for how often the respondents used their mobile phones is shown in Figure 3. The approximate amount of text messages/Instant Messages sent per day was fairly even across the sample as shown in Figure 3. The most popular application that the respondents' used their mobile phones for was sending text messages.

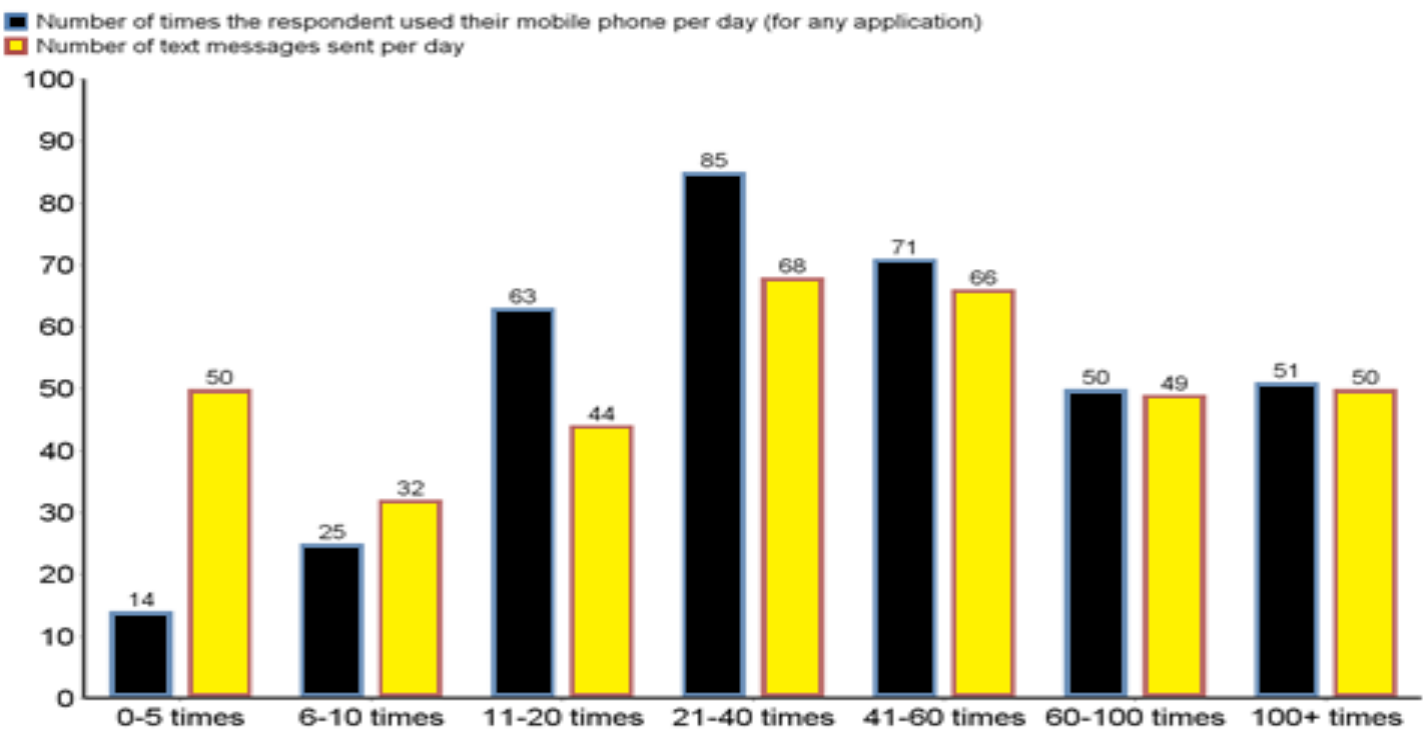

Figure 3: Bar graph showing the number of times respondents used their mobile phone (for any application) as well as how many text messages sent per day

Forty-seven percent (47\%) of the respondents received 1 call per day, and $42 \%$ made 1 call per day, and $46 \%$ made between 2 and 4 calls per day, and $41 \%$ received between 2 and 4 calls per day as shown in Figure 4. 




Figure 4: Bar graph showing approximate number of calls made and received per day for all the respondents

The majority of the calls were made to or from family (57\%), with the other calls being made to friends (37\%) and business (6\%). The average length of calls varied amongst the respondents. The most frequent average call length was 1-2 minutes (27\%), closely followed by 2-4 minutes (25\%), 0.5-1 minute (18\%), 4-8 minutes (13\%), 9+ minutes (12\%) and 0-30 seconds $(6 \%)$ as shown in Figure 5. Most of the respondents purpose for their calls made or received was for making, confirming and cancelling appointments/events $(55 \%)$ with the other respondents calling to maintain a social network, i.e. calling to say hello (39\%) and the remaining $6 \%$ made their calls for work purposes, family issues and advice and gossiping.

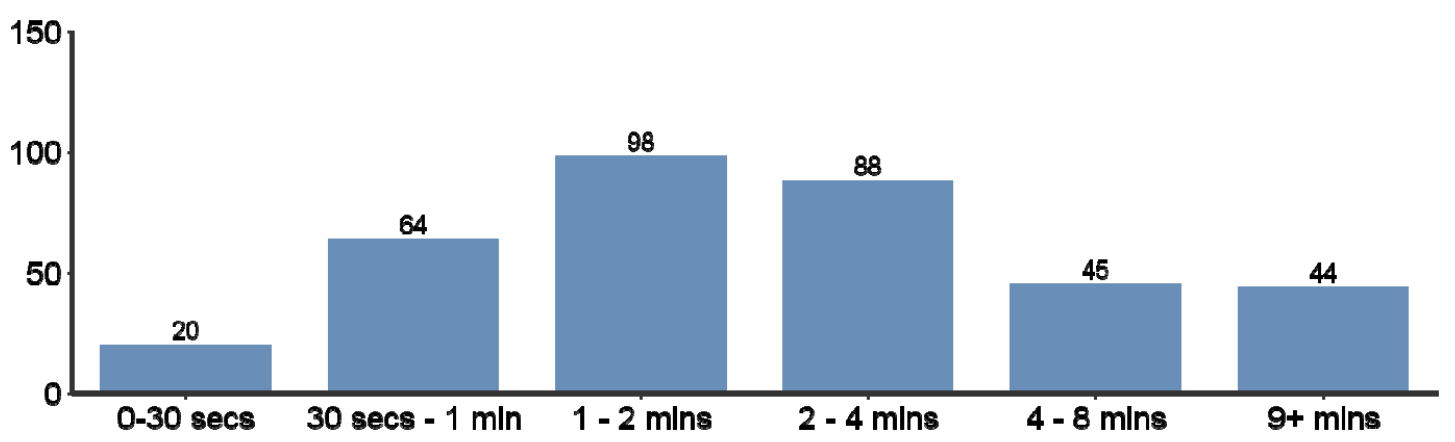

Figure 5: Bar graph showing average call length for all respondents

A gender analysis showed that there was a significant difference $(t=3.325, p=0.001)$ with respect to whom the majority of calls were made to or from. Female respondents made and received more calls from family (66\%) than male respondents $(48 \%)$. The male respondents made and received more calls to/from friends and business ( $42 \%$ and $9 \%$ respectively) than the female respondents (30\% and $2 \%$ respectively). The results showed a significant difference between genders for the average length of calls, with female respondents having a higher average length of call than male respondents $(\mathrm{t}=2.829, \mathrm{p}=0.005)$. The female respondents had a median range of 2-4 minutes and male respondents had a median range of 1-2 minutes with regard to average 
length of call as shown in Figure 6 . The main purpose for calls made and received similarly showed significant differences between male and female respondents $(t=2.405, \mathrm{p}=0.017)$, the male respondents made and received more calls to make, confirm or cancel appointments/events (Male $=61 \%$, Female $=48 \%$ ), whilst the females made more calls to maintain social networks with friends and family (Male $=32 \%$, Female $=44 \%$ ).

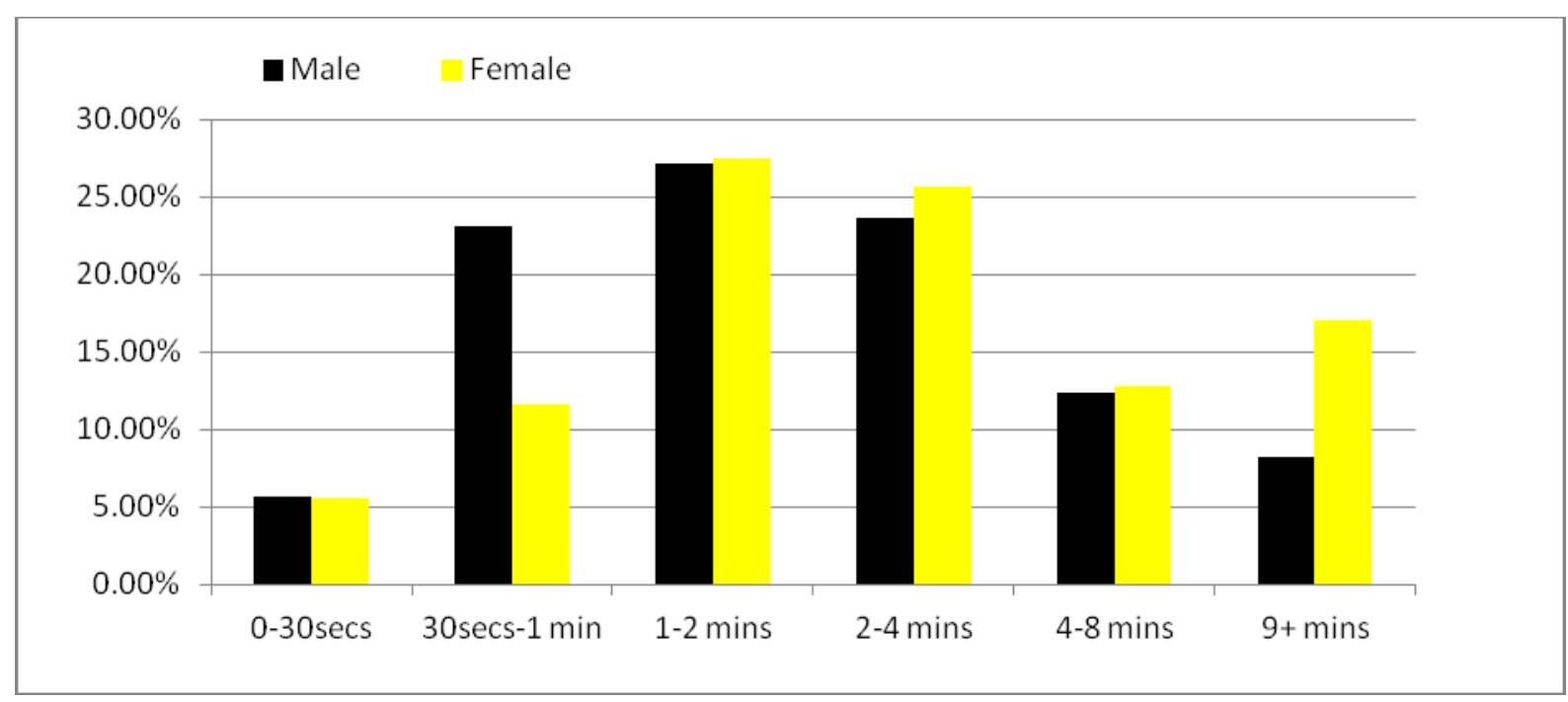

Figure 6: Bar chart showing average length of calls by male and female respondents

It is interesting to note that undergraduate respondents ( $85 \%$ of respondents) used their phones more often (for any application) $(p=0.016)$ as well as sent more text messages $(p=0.010)$ than the postgraduate respondents. However, the postgraduate respondents made $(p=0.057)$ and received $(\mathrm{p}=0.005)$ more calls than the undergraduate respondents. Undergraduate respondents were found to make/receive a lot more calls to/from family, whilst postgraduates mostly made/received more calls to/from friends.

Respondents that owned basic mobile phones used their phones (for any application) a lot less per day, whilst smart phone owners used their mobile phones the most. Smartphone owners similarly send more text messages per day than basic $(p=0.008)$ and feature phone $(p=0.002)$ owners. Respondents that are on a contract payment method seemed to make more calls $(p=0.050)$ and send more text messages $(\mathrm{p}=0.018)$ than respondents are on a prepaid scheme. This finding may be due to $85 \%$ of contract users' parents paying their bills.

\section{Purchasing Factors}

Table 3 shows the statements pertaining to mobile phone purchasing factors and their mean values and standard deviations. It is clear that the respondents emphasize more on usability and price when making decision on which mobile phone to purchase, as shown by the high mean values. Trend ranked as the least important purchasing factor amongst the respondents. 
North, Johnston, \& Ophoff

Table 3: Purchasing factors ordered in the rank of ascending mean values

\begin{tabular}{lcc}
\hline Statements & Mean & SD \\
\hline When purchasing a mobile phone, how important are these factors? & \\
Usability (ease of use, comfortable to hold) & 5.10 & 1.10 \\
Price & 4.89 & 1.37 \\
Brand & 4.42 & 1.40 \\
Aesthetic Values (look, colour, etc.) & 4.40 & 1.36 \\
Trend & 3.32 & 1.52 \\
\hline
\end{tabular}

Table 4 shows that significant differences exist with regard to brand $(t=3.610, p<0.001)$ and trend $(t=3.051, p=0.002)$, with the female respondents emphasizing more on these than the male respondents. At a 10\% significance level the male respondents seemed to emphasize more on usability (ease of use, comfortable to hold) than the female respondents $(t=1.677, p=0.095)$, whilst the females emphasized more aesthetic values (look, colour, etc.) than the males $(t=1.773$, $\mathrm{p}=0.077)$.

Table 4: t-test for purchasing factors based on genders

\begin{tabular}{lccl}
\hline Statements & t-value & p-value & Mean \\
\hline \multicolumn{2}{l}{ When purchasing a mobile phone, how important are these factors? } \\
Brand & 3.610 & 0.000 & $\mathrm{M}=4.18, \mathrm{~F}=4.70$ \\
Aesthetic Values (look, colour, etc.) & 1.773 & 0.077 & $\mathrm{M}=4.29, \mathrm{~F}=4.54$ \\
Price & 0.788 & 0.431 & $\mathrm{M}=4.84, \mathrm{~F}=4.96$ \\
Usability (ease of use, comfortable to hold) & 1.677 & 0.095 & $\mathrm{M}=5.19, \mathrm{~F}=4.99$ \\
Trend & 3.051 & 0.002 & $\mathrm{M}=3.09, \mathrm{~F}=3.58$ \\
\hline
\end{tabular}

It is interesting to note that the 18 and 19 year old respondents were a lot more concerned with the trend of a mobile phone, compared to the 20-25 year old respondents. The undergraduate respondents put more emphasis on brand than the postgraduate respondents $(p=0.018)$. Respondents that own Apple mobile phones were found to be a lot less worried about price and Blackberry owners were more concerned with the trend of a mobile phone than the other brand owners. Brand (Feature phone $(F) p=0.003$, Smart phone(S) $p=0.002)$, trend $(F p=0.004, S p=0.002)$ and aesthetic values $(\mathrm{F} \mathrm{p}=0.002, \mathrm{~S} \mathrm{p}=0.001)$ are a lot less important to respondents that own basic mobile phones (e.g. Nokia 1100) than respondents that own feature phones and smart phones. On the other hand price is a lot less important to respondents that own smartphones than basic phone and feature phone owners (Basic phone (B) $\mathrm{p}=0.001, \mathrm{~F} \mathrm{p}<0.001$ ). Respondents that pay for their own mobile phone are more concerned about the price of a mobile phone than respondents that did not pay for their own mobile phones $(\mathrm{p}=0.021)$. 


\section{Behaviour Related Issues}

Table 5 shows the statements and corresponding mean and standard deviation values concerning behaviour related issues with regard to mobile phone use. The results show that most of the respondents never turnoff their phone, use SMS/IM in class, always check their phones for missed calls or messages and get annoyed when others make or receive calls in lectures. Mean values lower than 2.00 indicate that the majority of respondents do not make or receive calls in lectures and have not been in excessive debt due to their mobile phone use.

Table 5: Behaviour related items ordered in the rank of ascending order

\begin{tabular}{lcc}
\hline Statements & Mean & SD \\
\hline I get annoyed when others make/receive calls in class/lectures & 4.71 & 1.78 \\
I never switch off my phone & 4.39 & 1.78 \\
I use SMS/ Instant Messaging (IM) in class & 4.38 & 1.65 \\
I always check for missed calls or messages & 4.33 & 1.52 \\
I only switch off my phone when the need arises (lecture, cinema etc.) & 3.93 & 1.91 \\
I feel distressed when my phone is not with me & 3.80 & 1.71 \\
I only switch off my phone when I do not want to be disturbed (study- & 3.28 & 1.88 \\
ing etc.) & & 1.59 \\
I feel distressed when someone doesn't answer my call & 3.16 & 1.68 \\
I am addicted to my mobile phone & 3.15 & 1.53 \\
I feel distressed when someone doesn't return my call & 3.03 & 2.47 \\
I make/answer calls when I am driving & 2.03 & 1.73 \\
I talk loudly into the phone even when I am in public & 1.42 & 0.97 \\
I make or receive calls when I am in a class/lecture & 1.30 & 0.88 \\
I have been in debt due to excessive mobile phone use & & \\
\hline
\end{tabular}

A gender analysis was performed, and the results are shown in Table 6. Significant differences were observed between the genders for always checking for missed calls or messages, feeling distressed when their phone is not with them and being addicted to their mobile phone, with the females (Mean $(\mathrm{M})=4.52, \mathrm{M}=4.00$ and $\mathrm{M}=3.37$ respectively) doing so more often than males $(\mathrm{M}=4.18, \mathrm{M}=3.64$ and $\mathrm{M}=2.96$ respectively). On the other hand, males $(\mathrm{M}=2.17$ and $\mathrm{M}=$ 2.79 respectively) were found to talk louder on their mobile phones and make or receive calls whilst driving than the females $(\mathrm{M}=1.87, \mathrm{M}=2.09$ respectively). At a $10 \%$ significance level 
the female respondents $(M=3.33)$ seemed to feel more distressed when someone did not answer their call as opposed to the male respondents $(\mathrm{M}=3.03)$.

Table 6: t-test for behaviour based on genders

\begin{tabular}{|c|c|c|c|}
\hline Statements & t-value & p-value & Mean \\
\hline I never switch off my phone & 0.132 & 0.895 & $\mathrm{M}=4.38, \mathrm{~F}=4.41$ \\
\hline $\begin{array}{l}\text { I only switch off my phone when the need arises } \\
\text { (lecture, cinema etc.) }\end{array}$ & 1.081 & 0.280 & $M=3.84, F=4.05$ \\
\hline $\begin{array}{l}\text { I only switch off my phone when I do not want to } \\
\text { be disturbed (studying etc.) }\end{array}$ & 0.124 & 0.902 & $\mathrm{M}=3.27, \mathrm{~F}=3.29$ \\
\hline I use SMS/ Instant Messaging (IM) in class & 1.156 & 0.248 & $\mathrm{M}=4.47, \mathrm{~F}=4.27$ \\
\hline $\begin{array}{l}\text { I make or receive calls when I am in a } \\
\text { class/lecture }\end{array}$ & 1.039 & 0.300 & $\mathrm{M}=1.46, \mathrm{~F}=1.36$ \\
\hline $\begin{array}{l}\text { I get annoyed when others make/receive calls in } \\
\text { class/lectures }\end{array}$ & 0.858 & 0.392 & $\mathrm{M}=4.79, \mathrm{~F}=4.63$ \\
\hline $\begin{array}{l}\text { I have been in debt due to excessive mobile } \\
\text { phone use }\end{array}$ & 0.652 & 0.515 & $\mathrm{M}=1.27, \mathrm{~F}=1.34$ \\
\hline I always check for missed calls or messages & 2.098 & 0.037 & $\mathrm{M}=4.18, \mathrm{~F}=4.52$ \\
\hline I feel distressed when my phone is not with me & 1.986 & 0.048 & $\mathrm{M}=3.64, \mathrm{~F}=4.00$ \\
\hline I am addicted to my mobile phone & 2.264 & 0.024 & $\mathrm{M}=2.96, \mathrm{~F}=3.37$ \\
\hline $\begin{array}{l}\text { I talk loudly into the phone even when I am in } \\
\text { public }\end{array}$ & 2.223 & 0.027 & $\mathrm{M}=2.17, \mathrm{~F}=1.87$ \\
\hline $\begin{array}{l}\text { I feel distressed when someone doesn't answer } \\
\text { my call }\end{array}$ & 1.790 & 0.074 & $\mathrm{M}=3.03, \mathrm{~F}=3.33$ \\
\hline $\begin{array}{l}\text { I feel distressed when someone doesn't return my } \\
\text { call }\end{array}$ & 1.471 & 0.142 & $\mathrm{M}=2.92, \mathrm{~F}=3.16$ \\
\hline I make/answer calls when I am driving & 3.936 & 0.000 & $\mathrm{M}=2.79, \mathrm{~F}=2.09$ \\
\hline
\end{tabular}

\section{Findings}

From the results the following findings are discussed regarding the motivations to use, purchasing factors, mobile phone usage pattern and behavioural issues relating to mobile phone use by UCT university students. 


\section{Reasons to Use Mobile Phones}

The study found a general consensus amongst UCT students for the reasons to use mobile phones, with the majority of them choosing socializing, safety and privacy. The high emphasis on socializing is in line with the literature which states that the most commonly found reason for owning a mobile phone by university students was the convenience of being able to contact others and be contacted regardless of time and location (Walsh et al., 2008). Robbery and crime are very prevalent in South Africa (Schönteich \& Louw, 2011), therefore it is not surprising that students regard safety as one of the primary reasons for using a mobile phone, in order to contact someone in an emergency (Walsh et al., 2010). As for privacy; the literature has shown how mobile phones provide freedom to university students, it provides a direct access to their friends without having to filter through parents or siblings as with a landline phone (Auter, 2007; Balakrishnan \& Raj, 2012). UCT students do not consider their mobile phones as a status symbol, which disagrees with literature from Malaysia, Netherlands and the USA (Balakrishnan \& Raj, 2012; Bouwman et al., 2008; Cotten et al., 2009), but is in line with the literature from New Zealand and the USA which says that mobile phones are no longer considered as a status symbol but as a necessity (Dresler-Hawke \& Mansvelt, 2008; Petruzzellis, 2010).

Gender analysis showed that UCT female students emphasized more on all the major reasons to use mobile phones, socializing, privacy and safety; this is coherent with the literature which states that female students feel stronger ties to their mobile phones than male students (Carbonell, Oberst, \& Beranuy, 2013; Grellhes1 \& Punyanunt-Carter, 2012). The female students showed a greater concern for safety than the male students, similar results were reported in the literature as female students are more vulnerable than male students and therefore rely on their mobile phones to contact people in an emergency (Balakrishnan \& Raj, 2012; Dresler-Hawke \& Mansvelt, 2008; Walsh, White, \& Young, 2010). The female respondents showed a greater interest in socializing with their mobile phones than the male respondents which was similarly found to be true in the literature when researching mobile phone usage patterns.

Female university students in the USA were found to have more conversations over mobile phones, and Malaysian university students were found to have lengthier conversations on their mobile phones than the male students (Balakrishnan \& Raj, 2012; Baron \& Campbell, 2010; Beaver et al., 2010)

\section{Mobile Phone Usage Pattern}

This study found large variances amongst the students with regard to how often they use their mobile phones. The majority of respondents (88\%) made between 0 and 4 calls per day and seemed to receive more calls than they made. These findings are somewhat consistent with Balakrishnan and Raj (2012) who found that university students in Malaysia make between 1 and 5 calls per day and also receive more calls than they made, which may be due to low budgets as the sample was comprised of students. The dominant use of mobile phones was found to be text messaging, with the majority of students (65\%) sending over 21 text messages a day, this is consistent with Brown et al. (2011) who discovered that text messaging was the most prevalent use of mobile phones by students in the USA.

Males and females were found to differ significantly in some areas of mobile phone use. The female respondents were found to have lengthier conversations and to make calls in order to maintain social network (i.e. calling to say hello) whilst the male respondents made calls that were shorter and more directed towards making, cancelling and confirming appointments or events. The same results were found in the USA and Malaysia where females generally have lengthier conversations than males and males generally make calls to make arrangements, whilst females are more likely to make calls for a social chat (Balakrishnan \& Raj, 2012; Grellhesl \& 
Punyanunt-Carter, 2012). Females were also found to talk more to their families on their mobile phones than the males, this is consistent with Chen and Katz (2009) study in the USA and Balakrishnan and Raj (2012) in Malaysia, where female university students are more likely to keep in contact with their family members, to share experiences and seek emotional support. While male university students only contact their parents "to keep them happy."

\section{Purchasing Factors}

Usability and price emerged as the most important factors considered when a UCT university student is purchasing a phone. Brand and aesthetic values were considered of above average importance, whilst trend was not an important purchasing factor to the students. The most common brand of mobile phone purchased by the students are Blackberry, Samsung and Apple, which are three of the top brands in the smartphone market, emphasizing that brand is important to the students. Tsai (2012) and Balakrishnan and Raj (2012) state that usability is not a factor taken into consideration by university students in Taiwan and Malaysia respectively, and that students are more interested in the entertainment features. For UCT university students, the opposite is true, usability (i.e. ease of use and comfortable to hold) is the most important purchasing factor. Half of the sample says they purchase their own mobile phone out of their pocket money, this may be the reason why price is a major factor for the students when purchasing a new mobile phone.

Gender analysis revealed that the female students were more interested in the trend, brand and the look of a mobile phone than the male students, who were more interested in the usability of their mobile phone. The results are consistent with literature in some countries but differ with literature in other countries. University students in the United Kingdom, Greece and Korea were found to have similar attributes to South African UCT university students with regards to females emphasizing more on the aesthetic values and males emphasizing more on the usability of their mobile phones (Economides \& Grousopoulou, 2009; Kim \& Park, in press; Ogunyemi, 2010). UCT university students' purchasing factors were found to be the opposite of Malaysian university students relating to brand and usability, female Malaysian university students were more interested in usability than the male students, who preferred to have the best brand (Balakrishnan \& Raj, 2012).

\section{Behavioural Issues}

Given the various benefits that mobile phones offer (e.g. ease of contact, privacy), it is not surprising that some students get attached to their mobile phones (Balakrishnan \& Raj, 2012). The literature states that mobile phone addiction is common among university students (Balakrishnan \& Raj, 2012; Chung, 2011; Dresler-Hawke \& Mansvelt, 2008; Walsh et al., 2008, 2010). The respondents in this study were found to identify with behavioural salience (i.e. regularly checking their phones for missed calls and messages); additionally most students reported that they felt distressed when their mobile phone was not with them further indicating their attachment to their mobile phones. The majority of respondents admitted to never switching off their mobile phones, this may similarly be a symptom of addiction. These findings are similar to that of Balakrishnan and Raj (2012) and Walsh et al. (2010), in which respondents reported feeling frustrated, angry and concerned when they could not access their mobile phone, and thus reflecting their underlying need to be constantly connected. Mobile phone addiction was more pronounced among the female respondents in this study, which is in accordance with Dresler-Hawke and Mansvelt (2008)'s findings in New Zealand where female university students showed a greater sign of addiction towards their mobile phone than male students.

Some respondents claimed to turn off their phone when the need arises (e.g. cinema, lectures). They also stated that they do not make or receive calls in lectures and they get annoyed when other people do so. This is a positive indication for UCT university students, a study by Campbell 
(2006) showed that phone calls in lectures diverts students and lecturers attention and is a serious problem. It is commendable that most of the respondents do not use voice communication in class, but most of the respondents admit to sending text messages in lectures. Sending messages in lectures, negatively affects the learning abilities of the students, as they are not able to concentrate (Balakrishnan \& Raj, 2012). Strivastava (2005) had similar findings in Switzerland, where students frequently sent text messages during lectures.

The male respondents were found to be a lot more likely to talk on their mobile phone while driving than the female respondents. The sample consists of students, and therefore not all of the students may own cars making the results for that particular question inconclusive.

It has been noted that female students, although being more likely to adopt mobile phone addiction, may have better mobile phone etiquette as they are less likely to talk loudly on their mobile phone whilst in public than the male students. This finding is in line with Dresler-Hawke and Mansvelt (2008) who found that female university students in New Zealand were more likely to adopt mobile phone addiction, but also had better mobile phone etiquette than male university students. Baron and Campbell (2010) also found that female university students in the USA had better politeness norms than make university students.

\section{Conclusion}

A structured questionnaire was used to examine the mobile phone usage pattern, purchasing factors, reasons to use and behavioural issues related to the use of mobile phones by 362 South African university students, the majority of whom were from UCT. There is no definitive literature on how South African university students use mobile phones (Kreutzer, 2009), and therefore cultural influences were not considered. However, the findings were compared with findings from around the world on how university students use mobile phones. Furthermore, a gender analysis was conducted to see if male and female university students use mobile phones differently and for different reasons.

Research question 1 asked what are the reasons for using a mobile phone among university students. The main findings discovered that the main reason UCT university students use a mobile phone is for socializing, as well as for safety and privacy purposes, with female respondents emphasizing more on safety and socializing, this is in line with the findings of Balakrishnan and Raj (2012). Most of the respondents socialized with family and friends through their mobile phones, with female respondents emphasizing more on family whilst the male respondents were more inclined to socialize with their friends.

Regarding usage (research question 2), the study found large variances with the majority of respondents (88\%) making between 0 and 4 calls per day and receiving more calls than they made, consistent with what Balakrishnan and Raj (2012) found. Text messaging was found to be the dominant use of mobile phones, with $65 \%$ of students sending over 21 text messages a day.

The findings show that the respondents emphasize more on usability and price when making purchasing decisions (research question 3) on which mobile phone to purchase, rather than brand, trend and price as in the study by Balakrishnan and Raj (2012). The females were a lot more interested in the brand and trend when purchasing a new mobile phone than the males.

Regarding behavioural issues (research question 4), the respondents showed signs of addiction to their mobile phones as found by Balakrishnan and Raj (2012), with the female respondents showing greater signs of addiction. The results show that most of the respondents never turn off their phone, use SMS/IM in class and always check their phones for missed calls or messages. It is also interesting to note that almost all the respondents have never been in debt due to excessive mobile phone use, in agreement with Balakrishnan and Raj (2012). 
This research could have practical benefits to marketers, mobile phone developers, universities, and parents in South Africa. One of the educational ironies of today, is that students are absorbed in technology in all aspects of their lives except for university (Johnston, 2013). Academics should include mobile phones in their teaching methods, and should make teaching materials available on mobile phones. Academics should use mobile phones to communicate with students.

The findings from this study may be used as a foundation for other researchers who intend to examine how mobile phones are used, as well as other issues relating to it. The reasons why academics are not using mobile phones in their teaching could be one area for research.

The study is the first of its kind in South Africa and therefore opens up a pathway for further research into the subject.

\section{Acknowledgement}

This work is based on the research supported in part by the National Research Foundation of South Africa (Grant Number 91022).

\section{References}

Auter, P. J. (2007). Portable social groups: Willingness to communicate, interpersonal communication gratifications, and cell phone use among young adults. International Journal of Mobile Communications, 5(2), 139-155.

Balakrishnan, V., \& Raj, R. G. (2012). Exploring the relationship between urbanized Malaysian youth and their mobile phones: A quantitative approach. Telematics and Informatics, 29(3), 263-272.

Baron, N., \& Campbell, E. (2010). Talking takes too long: Gender and cultural patterns in mobile telephony. In conference of Association of Internet Researchers. Göteborg, Sweden.

Beaver, T., Knox, D., \& Zusman, M. (2010). “Hold the phone!”: Cell phone use and partner reaction among university students. College Student Journal, 44(3), 629-632.

Bouwman, H., Carlsson, C., Walden, P., \& Molina-Castillo, F. J. (2008). Reconsidering the actual and future use of mobile services. Information Systems and e-Business Management, 7(3), 301-317.

Brown, K., Campbell, S. W., \& Ling, R. (2011). Mobile phones bridging the digital divide for teens in the US? Future Internet, 3(4), 144-158.

Campbell, S. W. (2006). Perceptions of mobile phones in college classrooms: Ringing, cheating, and classroom policies. Communication Education, 55(3), 280-294.

Carbonell, X., Oberst, U., \& Beranuy, M. (2013). The cell phone in the twenty-first century : A risk for addiction or a necessary tool? In P. M. Miller (Ed.), Principles of addiction (pp. 901-909). San Diego.

Chen, Y.-F., \& Katz, J. E. (2009). Extending family to school life: College students' use of the mobile phone. International Journal of Human-Computer Studies, 67(2), 179-191.

Chigona, W., Kamkwenda, G., \& Manjoo, S. (2008). Uses and gratifications of mobile Internet among South African students. SA Journal of Information Management, 10(3). Retrieved from http://www.sajim.co.za/index.php/SAJIM/article/view/329/321

Chung, N. (2011). Korean adolescent girls' addictive use of mobile phones to maintain interpersonal solidarity. Social Behavior and Personality: An International Journal, 39(10), 1349-1358.

Cotten, S. R., Anderson, W. A., \& Tufekci, Z. (2009). Old wine in a new technology, or a different type of digital divide? New Media \& Society, 11(7), 1163-1186.

Dresler-Hawke, E., \& Mansvelt, J. (2008). Mobile phones: Enhancing social communication in young adult's lives? Presentation at the Australian and New Zealand Marketing Academy Conference (pp. 17). Sydney, Australia. 
Economides, A. A., \& Grousopoulou, A. (2009). Students' thoughts about the importance and costs of their mobile devices' features and services. Telematics and Informatics, 26(1), 57-84.

Grellhesl, M., \& Punyanunt-Carter, N. M. (2012). Using the uses and gratifications theory to understand gratifications sought through text messaging practices of male and female undergraduate students. Computers in Human Behavior, 28(6), 2175-2181.

Hargittai, E., \& Kim, S. J. (2010). The prevalence of smartphone use among a wired group of young adults. Institute for Policy Research Northwestern University. Chicago.

Hong, F.-Y., Chiu, S.-I., \& Huang, D.-H. (2012). A model of the relationship between psychological characteristics, mobile phone addiction and use of mobile phones by Taiwanese university female students. Computers in Human Behavior, 28(6), 2152-2159.

International Telecommunication Union. (2013). ICT Statistics. Retrieved from http://www.itu.int/en/ITUD/Statistics/Pages/stat/default.aspx

Jackson, L. A, Zhao, Y., Kolenic, A., Fitzgerald, H. E., Harold, R., \& Von Eye, A. (2008). Race, gender, and information technology use: The new digital divide. Cyberpsychology \& Behavior : The Impact of the Internet, Multimedia and Virtual Reality on Behavior and Society, 11(4), 437-42.

Jackson, L. A., Von Eye, A., Fitzgerald, H. E., Zhao, Y., \& Witt, E. A. (2010). Self-concept, self-esteem, gender, race and information technology use. Computers in Human Behavior, 26(3), 323-328.

Johnston, K. A. (2013). A guide to educating different generations in South Africa. Issues in Informing Science and Information Technology, 10, 261-273. Retrieved from http://iisit.org/Vol10/IISITv10p261-273Johnston0062.pdf

Karjaluoto, H., Karvonen, J., Kesti, M., Koivumäki, T., Manninen, M., Pakola, J., Ristola, A., et al. (2005). Factors affecting consumer choice of mobile phones: Two studies from Finland. Journal of Euromarketing, 14(3), 59-82.

Katz, J. E., \& Aakhus, M. (2002). Perpetual contact: Mobile communication, private talk, public performance. Cambridge, England: Cambridge University Press.

Kim, M.-J., \& Park, J. (in press). Mobile phone purchase and usage behaviors of early adopter groups in Korea. Behaviour \& Information Technology.

Kreutzer, T. (2009). Internet and online media usage on mobile phones among low-income urban youth in Cape Town. International Journal of Education and Development using ICT, 5(5), 1-21.

Lenhart, A., Ling, R., Campbell, S., \& Purcell, K. (2010). Teens and mobile phones. Pew Internet and American Life Project (Vol. 20, pp. 1-94). Washington D.C.

Leung, L. (2007). Unwillingness-to-communicate and college students' motives in SMS mobile messaging. Telematics and Informatics, 24(2), 115-129.

Leung, L., \& Wei, R. (2000). More than just talk on the move: Uses and gratifications of the cellular phone. Journalism \& Mass Communication Quarterly, 77(2), 308-320.

Levy, Y., \& Ellis, T. J. (2006). A systems approach to conduct an effective literature review in support of information systems research. Informing Science: International Journal of an Emerging Transdiscipline, 9(1), 181-212. Retrieved from http://www.inform.nu/Articles/Vol9/V9p181212Levy99.pdf

Ling, R., Bertel, T. F., \& Sundsoy, P. R. (2011). The socio-demographics of texting: An analysis of traffic data. New Media \& Society, 14(2), 281-298.

Ling, R., \& Horst, H. (2011). Mobile communication in the global south. New Media \& Society, 13(3), 363-374.

Lobo, D., \& Joshma, P. J. (2013). A study to assess the impact of mobile phone use on various dimensions of students' life in a selected institution of Mangalore. International Journal of Nursing Education, $5(2), 62-65$. 
Mehrotra, A., \& Nguyen, A. (2012). Differences in phone use between men and women: Quantitative evidence from Rwanda. In Proceedings of the Fifth International Conference on Information and Communication Technologies and Development (pp. 297-306). California: ACM.

Monette, D. R. (2013). Applied social research: A tool for the human services. Stamford, USA: Cengage Learning.

Ogunyemi, O. (2010). Consumption and (in)appropriate use of mobile phone among teenage Africans in the UK. Lincolnshire, England.

Petruzzellis, L. (2010). Mobile phone choice: Technology versus marketing. The brand effect in the Italian market. European Journal of Marketing, 44(5), 610-634.

Roberson, J. H., \& Hagevik, R. A. (2008). Cell phones for education. Meridian, 11(2), 1-5.

Schönteich, M., \& Louw, A. (2011). Crime in South Africa : A country and cities profile. Institute for Security Studies, (49), 1-17.

Shao, G. (2009). Understanding the appeal of user-generated media: A uses and gratification perspective. Internet Research, 19(1), 7-25.

Shin, D.-H. (2010). Understanding e-book users: Uses and gratification expectancy model. New Media \& Society, 13(2), 260-278.

Srivastava, L. (2005). Mobile phones and the evolution of social behaviour. Behaviour \& Information Technology, 24(2), 111-129.

Suominen, A., Hyrynsalmi, S., \& Knuutila, T. (2014). Young mobile users: Radical and individual - Not. Telematics and Informatics, 31(2), 266-281.

Tsai, M. (2012). The trends and adoption behaviors of smart phones in Taiwan : A comparison between persons over 45 years of age and youth under 25.2012 Proceedings of Technology Management for Emerging Technologies (PICMET) (pp. 1456-1462). IEEE.

Walsh, G., \& Kelly, R. (2012). Cell phones and student achievement: A literature review. [A paper to fulfill partial requirements for education.] Memorial University of Newfoundland.

Walsh, S., White, K., \& Young, R. (2008). Over-connected? A qualitative exploration of the relationship between Australian youth and their mobile phones. Journal of Adolescence, 31(1), 77-92.

Walsh, S., White, K., \& Young, R. (2010). Needing to connect: The effect of self and others on young people's involvement with their mobile phones. Australian Journal of Psychology, 62(4), 194-203.

Wei, R. (2008). Motivations for using the mobile phone for mass communications and entertainment. Telematics and Informatics, 25(1), 36-46.

Welman, C., Kruger, F., \& Mitchell, B. (2005). Research methodology. Oxford: Oxford University Press.

\section{Biographies}

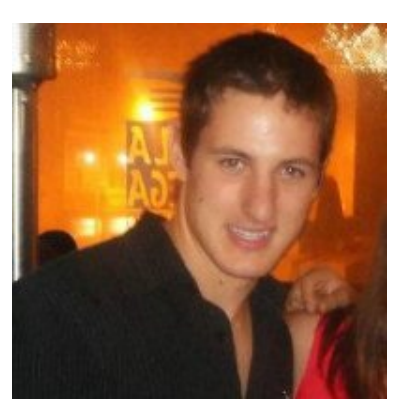

David North completed his post graduate degree in the Department of Information Systems at the University of Cape Town in 2013. 


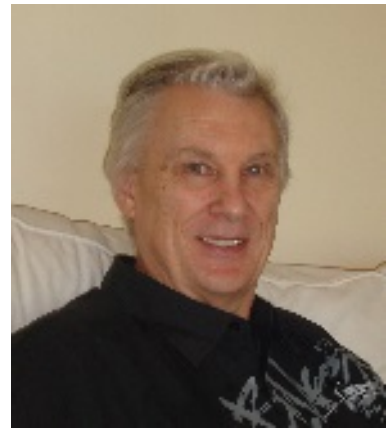

Kevin Johnston is an Associate Professor in the Department of Information Systems at the University of Cape Town. He worked for 24 years for companies such as De Beers, Liberty Life, Legal \& General and BoE. Kevin's main areas of research are ICT Strategic Management, IS educational issues, IS-related social issues and Open Source Software.

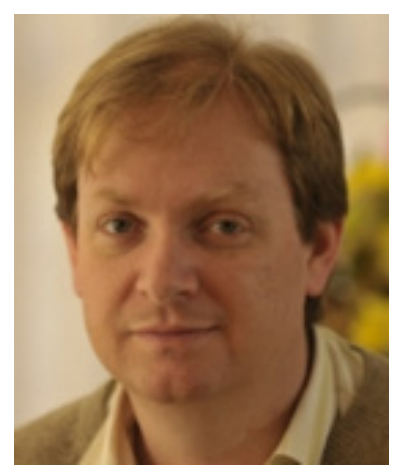

Jacques Ophoff is a Senior Lecturer in the Department of Information Systems at the University of Cape Town (UCT), South Africa. He obtained his doctorate in Information Technology from the Nelson Mandela Metropolitan University, South Africa. Before joining UCT he was an IT Product Manager at an online startup company. His research interests include information security, mobile technologies, and education. 